\title{
An Investigation on the Reliability and Degradation of Polycrystalline Silicon Solar Cells Under Accelerated Corrosion Test
}

\author{
SEBASTIAN MARIAN ZAHARIA ${ }^{1}$, MIHAI ALIN POP2*, LUCIA ANTONETA CHICOS ${ }^{1}$, CAMIL LANCEA ${ }^{1}$, AUGUSTIN SEMENESCU ${ }^{3}$, \\ BOGDAN FLOREA 3 OANA ROXANA CHIVU 4 \\ 'Transilvania University of Brasov, Faculty of Technological Engineering and Industrial Management, Department of Manufacturing \\ Engineering, 5 Mihai Viteazu Str., 500174, Brasov, Romania \\ 2Transilvania University of Brasov, Faculty of Materials Science and Engineering, Department of Materials Science, 1 Colina \\ Universitatii Str., 500084, Brasov, Romania \\ ${ }^{3}$ University Politehnica of Bucharest, Faculty of Material Science and Engineering, 313 Splaiul Independentei, 060021, Bucharest, \\ Romania \\ ${ }^{4}$ University Politehnica of Bucharest, Faculty of Engineering and Management of Technological Systems, 313 Splaiul Independentei, \\ 060021, Bucharest, Romania
}

Using the reliability accelerated tests in the early stage of solar cells life cycle, by using an high level of stress, in order to highlight the one or more degradation factors, on which could be quicklyacquired a series of the experimental data, leads to point out the design errors of solar cells and to predictive assessment of reliability indicators. Environmental factors influence the lifetime of a solar cell. The action of each factors determines its aging and finally its degradation as the result of the combined action of sunlight, emissions, climate change, temperature and humidity, the action of dust, the saturated air from the proximity of oceans and seas, whose actions a solar cell undergoes during normal operation. In this paper has been analysed 10 polycrystalline solar cells subjected to accelerated corrosion tests. It has been also carried out two analyses, the first a quantitative analysis by determining the values of reliability indicators and the second one was a qualitative analysis of the degradation of polycrystalline solar cells using the optical microscope.

Keywords: solar cells, reliability, degradation analysis, accelerated corrosion test, mean life

The operation of solar cells is based on the physical process of converting sunlight into electricity at the atomic level. The photoelectric effect is the property of materials of absorbing the photons and then of releasing the electrons. In the case of solar cells, these electrons are trapped and resulting an electric current which can be used as electricity. Depending on the nature of the crystalline semiconductor material used in the manufacture of solar cells, these can be classified into three categories: monocrystalline cells, polycrystalline cells, and amorphous or thin-film solar cells [1]. Polycrystalline solar cells are manufactured by casting the liquid silicon into blocks which are then cut into thin layers. Polycrystalline solar cells have a granular structure and are best used cells at industrial level for the manufacture of photovoltaic panels having the best quality-price ratio. These types of cells behave well at high temperatures and have an efficiency thatcan reach about $12 \%$ - 14\%. If the solar cells are unable to generate power it is obvious that there is a failure which can be treated in terms of reliability. However, degradation due to environmental factors, such as corrosion can cause a gradual decrease of energy production representing the durability of solar cells (which actually means a lack of durability of solar cells). These issues of durability ultimately can cause the damage of the solar cell.

The reliability and durability of solar cells are two important aspects of their life cycle, as important as their manufacturing cost and efficiency. Recent studies [3-6] have been made regarding manufacturing, reliability and durability of crystalline silicon (c-Si) photovoltaic (PV) module. Polycrystalline solar cells are found in various places around the world and are designed to produce energy for homes and power plants of various sizes.
Depending on where and how they are installed, the solar cells are subjected to different stress factors (fig. 1).

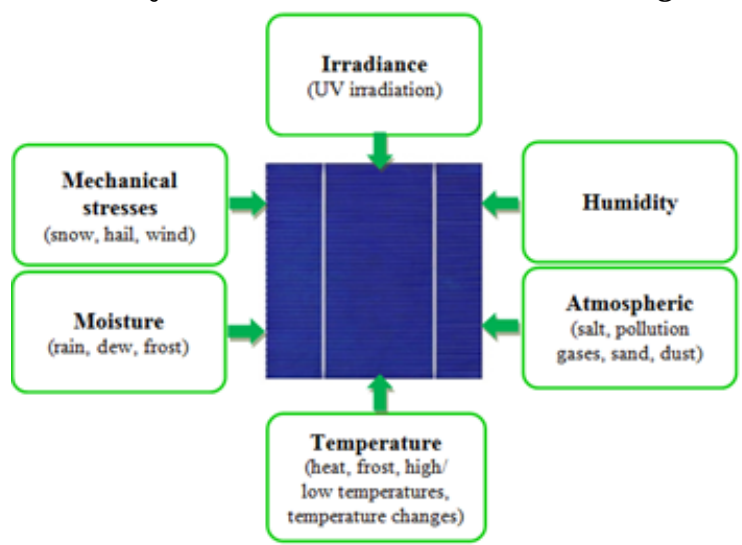

Fig. 1. Stresses occurred during using solar cells $[7,8]$

Failures of solar cells, because of corrosion, can be generated by the causes shown in figure 2 .

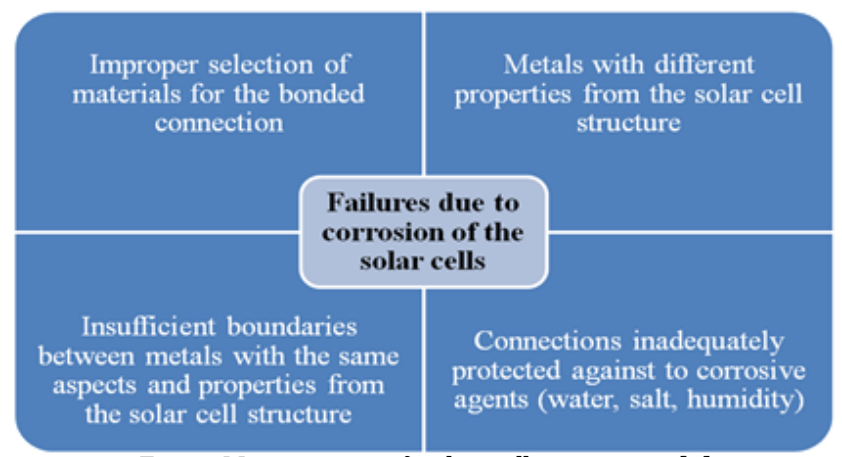

Fig. 2. Main causes of solar cells corrosion [9]

\footnotetext{
* email: mihai.pop@unitbv.ro
} 
A reliable photovoltaic ( $P V$ ) module may be defined as a PV module that has a high probability of performing its function adequately for 30 years under the operating conditions encountered in various environments [10]. The main ways of degradation of PV (corrosion, discoloration, delamination and breakage) and computational models associated with these modes of degradation have been identified in various researches $[8,11]$.

A recentstudy [12] investigated the corrosion behaviour of three types of crystalline silicon (C-Si) solar cells at aging tests in indoor environment $\left(25^{\circ} \mathrm{C}, 45 \% \mathrm{RH}, 0-2\right.$ months), cells immersing in moisture atmosphere $\left(25^{\circ} \mathrm{C}, 85 \% \mathrm{RH}\right.$, $0-240 \mathrm{~h}$ ) and cells immersing in acetic acid atmosphere $\left(25^{\circ} \mathrm{C}, 85 \% \mathrm{RH}, 0-240 \mathrm{~h}\right)$. The most important and studied tests on solar cells are the accelerated aging tests [13, 14, $15]$. Ageing of solar cells leads to lower efficiency by $10 \%$ in 25 years.

In [16] has been developed an extensive study on accelerated aging tests on a wide variety of solar cells (on five differentPV technologies Mono, Multi, a-Si, CdTe, CIGS). For these types of technologies have been analysed various parameters (maximum power, efficiency cell and module efficiency) in different ranges of temperature and humidity in certain testing time period.

Testing of solar cells in their environment of use requires a much too long. Manufacturers of solar cell cannot wait 25-30 years or even longer to analyse and then introducing a new product on the market. Therefore, they have developed the accelerated test techniques [17-19] in order to shorten the test time to days or weeks at most, and then to place on the market new solar cells manufactured and tested.

In this paper, using accelerated testing techniques, have been tested to corrosion 10 polycrystalline solar cells at two levels of immersion of 5 and $10 \% \mathrm{NaCl}$ concentration solutions (by weight). Results from corrosion accelerated tests were used to determine the main indicators of reliability. Analysis and measurements regarding the corrosion and deposits of salt on the polycrystalline solar cells have been carried out by optical microscopy.

\section{Experimental part \\ Materials}

Polycrystalline solar cells tested in current paper are shown in figure 3 and they have the characteristics presented in table 1.

The main advantages of polycrystalline solar cells studied in this paper are the following: lower per panel cost, stop conductivity, good adhesion, superior weldability, nice appearance, durability and longevity, lower electric bills.

\section{Testing procedure}

Polycrystalline solar cells are electrical components that are exposed outdoors throughout their life span. The wet atmosphere, strong corrosive, can degrade some components of solar cells (corrosion of metal components,

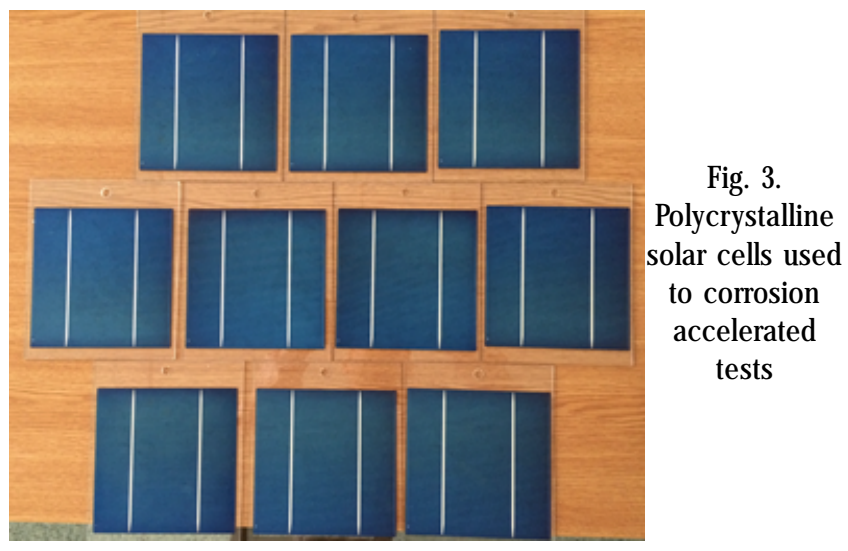

damaging properties of nonmetallic materials - such as protective coatings or plastic - by assimilating of salts) at the same time causing permanent damage.

The 10 solar cells were studied to corrosion through subjecting them to salt spray tests under 5 and $10 \% \mathrm{NaCl}$ solution concentration (by weight). For corrosion accelerated testing, polycrystalline solar cells have been glued onto a sheet of plastics to be disposed in saline chamber (fig. 4). Regarding the positioning of specimens in the salt spray chamber, the inclination to the vertical of the face of the module normally exposed to solar irradiance shall be 15 to $30^{\circ}$.

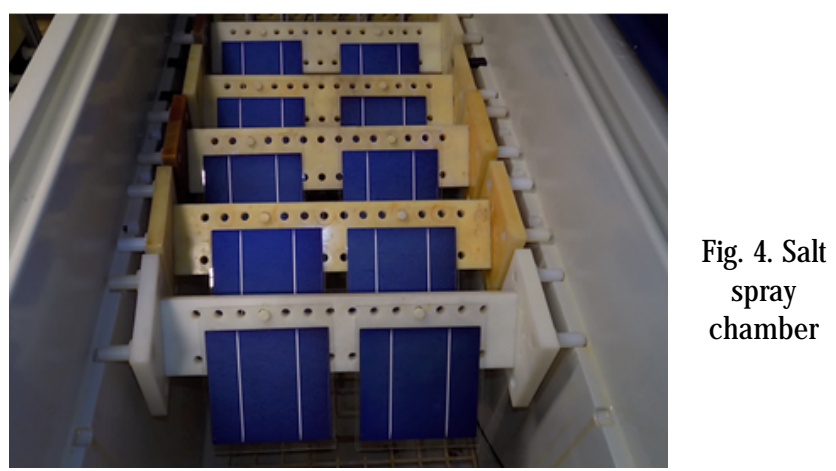

Tests were carried out following the procedure established in IEC 61701 - Salt mist corrosion testing of photovoltaic (PV) modules and ASTM B117 - Standard Practice for Operating Salt Spray (Fog) Apparatus. The scope of this test is to determine the resistance of the polycrystalline solar cells to corrosion from salt spray. This test is useful for evaluating the compatibility of materials, and the quality and uniformity of protective coatings. The 10 specimens were evaluated with regard to corrosion and deposits of salt, at four inspection intervals: 96, 192, 288 and 384 hours. Inspections were carried out both visually and using Omnimet-Buehler microscope system provided with a Nikon microscope (with a resolution up to 1000x) for structural analysis. In table 2 the main accelerated testing conditions of the 10 polycrystalline solar cells using salt spray corrosion test are presented.

After completing the tests in the salt chamber, polycrystalline solar cells were washed and then dried for

\begin{tabular}{|l|l|}
\hline Characteristic & Value \\
\hline Type & Polycrystalline solar cells with two strips \\
\hline Size [mm] & $156 \times 156$ \\
\hline Thickness [mm] & 0.2 \\
\hline Maximum Power [W] & 3.7 \\
\hline Optimum operating voltage [V] & 0.57 \\
\hline Cell efficiency & $14-17 \%$ \\
\hline Operating temperature & $-40^{\circ} \mathrm{C}$ to $+80^{\circ} \mathrm{C}$ \\
\hline
\end{tabular}

Table 1

POLYCRYSTALLINE SOLAR CELLS CHARACTERISTICS 


\begin{tabular}{|l|l|}
\hline \multicolumn{2}{|c|}{ Salt spray corrosion test procedure } \\
\hline Inclination to the vertical of the face of solar cells & $15^{\circ}-30^{\circ}$ \\
\hline Duration & $384 \mathrm{~h}$ \\
\hline PH value of salt solution & $6.5-7.2$ \\
\hline Salt solution concentration (by weight) & $5 \%$ and $10 \%$ \\
\hline Temperature of test chamber & $35^{\circ} \mathrm{C}$ \\
\hline Temperature of salt solution & $35^{\circ} \mathrm{C} \pm 2^{\circ} \mathrm{C}$ \\
\hline 24 h. Subsequently the specimens were subjected to the extrap
\end{tabular}

Table 2

SALT SPRAY CORROSION TEST CONDITIONS procedure of degradation analysis.

\section{Results and discussions}

Accelerated degradation analysis under salt spray test of the polycrystalline solar cells

Accelerated degradation analysis under salt spray test of the polycrystalline solar cells involves measuring and

extrapolating the degradation or the information regarding the operating performance. Most of failure mechanisms can be directly linked to the degradation of the solar cell components and the degradation analysis allows the user to extrapolate the measured data in a specific time of failure, based on the degradation measurements or on their performance over time. When using accelerated testing techniques, in order to reduce the testing time, the obtained

\begin{tabular}{|c|c|c|c|}
\hline $\begin{array}{c}\text { Inspection Time } \\
{[\mathrm{hrs}]}\end{array}$ & $\begin{array}{c}\text { Degradation } \\
{\left[\mathrm{mm}^{2}\right]}\end{array}$ & $\begin{array}{c}\text { Sodium Chloride } \\
{[\mathrm{NaCl} \%]}\end{array}$ & $\begin{array}{l}\text { Specimen } \\
\text { No. }\end{array}$ \\
\hline 96 & 12.4 & 5 & 1 \\
\hline 192 & 17.7 & 5 & 1 \\
\hline 288 & 23.5 & 5 & 1 \\
\hline 384 & 54.9 & 5 & 1 \\
\hline 96 & 14.6 & 5 & 2 \\
\hline 192 & 17.5 & 5 & 2 \\
\hline 288 & 35.9 & 5 & 2 \\
\hline 384 & 51.2 & 5 & 2 \\
\hline 96 & 15.2 & 5 & 3 \\
\hline 192 & 22.9 & 5 & 3 \\
\hline 288 & 34.9 & 5 & 3 \\
\hline 384 & 67.6 & 5 & 3 \\
\hline 96 & 11.4 & 5 & 4 \\
\hline 192 & 39.8 & 5 & 4 \\
\hline 288 & 78.9 & 5 & 4 \\
\hline 384 & 101.4 & 5 & 4 \\
\hline 96 & 18.7 & 5 & 5 \\
\hline 192 & 35.6 & 5 & 5 \\
\hline 288 & 98.8 & 5 & 5 \\
\hline 384 & 145.5 & 5 & 5 \\
\hline 96 & 44.7 & 10 & 6 \\
\hline 192 & 128.6 & 10 & 6 \\
\hline 288 & 456.2 & 10 & 6 \\
\hline 384 & 845.6 & 10 & 6 \\
\hline 96 & 149.8 & 10 & 7 \\
\hline 192 & 434.2 & 10 & 7 \\
\hline 288 & 757.8 & 10 & 7 \\
\hline 384 & 1078.3 & 10 & 7 \\
\hline 96 & 225.7 & 10 & 8 \\
\hline 192 & 526.9 & 10 & 8 \\
\hline 288 & 767.5 & 10 & 8 \\
\hline 384 & 993.7 & 10 & 8 \\
\hline 96 & 367.5 & 10 & 9 \\
\hline 192 & 637.7 & 10 & 9 \\
\hline 288 & 931.8 & 10 & 9 \\
\hline 384 & 1209.7 & 10 & 9 \\
\hline 96 & 489.2 & 10 & 10 \\
\hline 192 & 636.1 & 10 & 10 \\
\hline 288 & 976.9 & 10 & 10 \\
\hline 384 & 1191.3 & 10 & 10 \\
\hline
\end{tabular}

Table 3

ACCELERATED DEGRADATION DATA OF THE POLYCRYSTALLINE SOLAR CELLS 
measurements of degradation within an accelerated stress level can be extrapolated to the normal conditions of using the solar cells.

For the statistical processing of experimental data obtained from accelerated corrosion tests was used the software ALTA 7. This software program allows performing an analysis of degradation using various models of degradation: linear, exponential, power, logarithmic, Gompertz and Lloyd-Lipow models. The Power model was the model used for analysing the degradation of polycrystalline solar cells. This model of degradation is based on the following equation:

$$
y=b \cdot x^{a}
$$

where $y$ is the degradation measurement, $x$ is the inspection time and $a, b$ and $c$ are model parameters.

This model may be used to predict when the degradation of a solar cell will reach the predefined failure level. The predicted time can be taken as the failure time. Once the Power model parameters were estimated for each solar cell, $x_{i}$ can be extrapolated using the critical value defined by the degradation of $y$. The value of $x$, calculated from all the solar cells may be used as a failure time for further analysis of the reliability accelerated tests. Sets of five polycrystalline solar cells were tested under salt spray tests under 5 and $10 \% \mathrm{NaCl}$ solution concentration (by weight), by using the degradation analysis. The solar cells have been cyclically tested and were inspected within a time period of $96 \mathrm{~h}$ to observe the salt deposits or the appearance of the corrosion phenomena. The defect is defined as a salt deposit of $1 \mathrm{~mm}$ or more. In the table 3 are presented the degradation test results for ten solar cells with every checked time interval.

The Degradation vs. Time plot (fig. 5) describes how the performance of each polycrystalline solar cells degrades over the time. The pink line, placed at the bottom of the figure 5 , indicates the level of the critical degradation of 1 $\mathrm{mm}^{2}$ as a surface of salt deposition or as a corrosion of the solar cell.

By using the model Power model the degradation data were extrapolated on failure times corresponding of certain reliability accelerated tests. The reliability tests have a special importance aiming either to determine the reliability characteristics of a product or to check them if they are established in a predictive (forecasting) mode. In the case of more complex products, this check is carried outoperationally (in operation). The reliability tests are badly needed and have a decisive role in improving the technical solutions and in raising the product performances. The essential issue of the reliability tests consists of the testing time which is, generally, comparable to the useful lifecycle of the product. An excessive testing duration can make inefficient the reliability test, from economic point of view. The reliability tests can be done in normal operation regime or accelerated regime. Accelerated reliability tests are performed by forcing (accelerating) the normal operating regime of the product [20]. This is achieved by increasing the rate and/or the stress level in relation to its normal operation in order to reduce the testing time and the material costs related to these tests. Data regarding the operation in accelerated regime are extrapolated using the relationship between the operating time and the stress in order to estimate the following indicators [21]: the mean

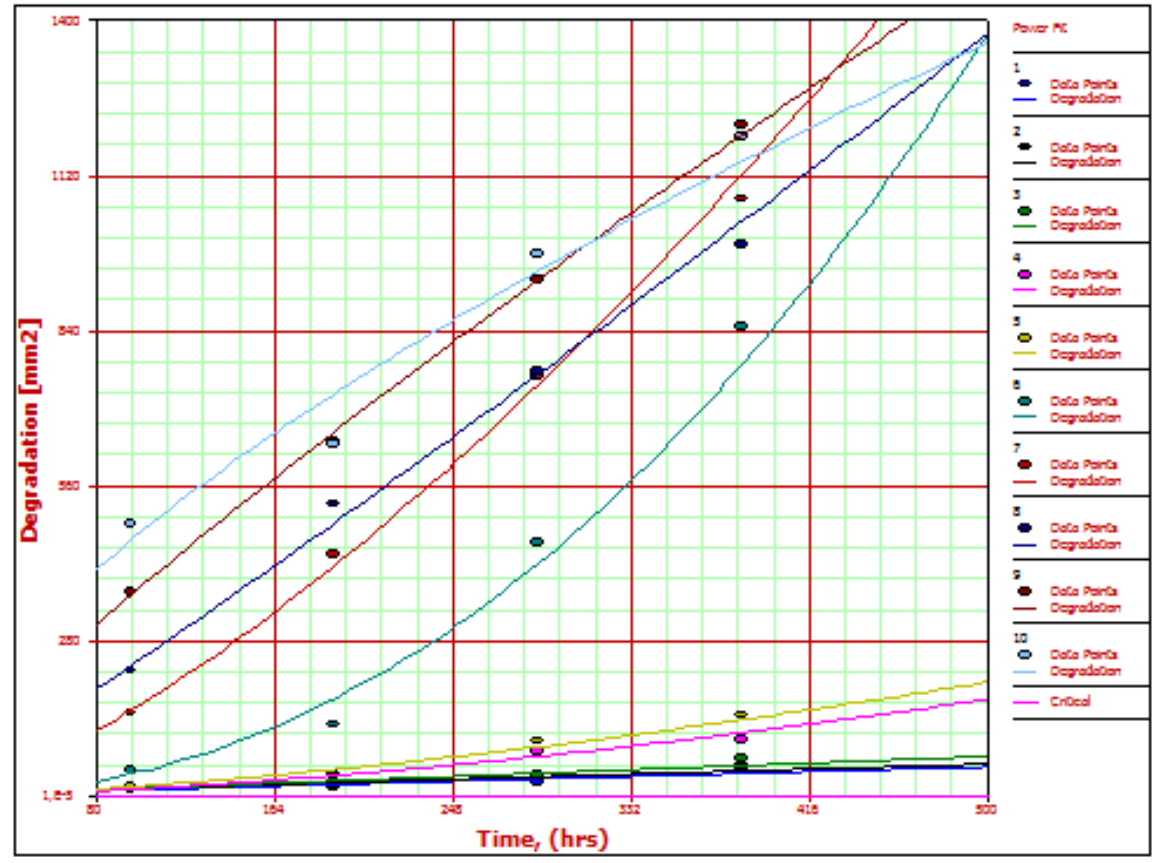

\begin{tabular}{|c|c|c|c|c|}
\hline $\begin{array}{c}\text { Time to failure } \\
\text { [hrs] }\end{array}$ & Reliability & Unreliability & PDF & Failure rate \\
\hline 90 & 0.933 & 0.067 & 0.020147 & 0.0000599 \\
\hline 4463 & 0.837 & 0.163 & 0.006113 & 0.0000148 \\
\hline 6466 & 0.741 & 0.259 & 0.005495 & 0.0000127 \\
\hline 31029 & 0.644 & 0.356 & 0.003546 & 0.0000058 \\
\hline 166050 & 0.548 & 0.452 & 0.002268 & 0.0000014 \\
\hline 224025 & 0.451 & 0.549 & 0.002099 & 0.0000010 \\
\hline 269293 & 0.355 & 0.645 & 0.002002 & 0.0000008 \\
\hline 320704 & 0.258 & 0.742 & 0.001914 & 0.0000006 \\
\hline 353538 & 0.162 & 0.838 & 0.001867 & 0.0000005 \\
\hline 772803 & 0.066 & 0.934 & 0.001534 & 0.0000001 \\
\hline
\end{tabular}

MATERIALE PLASTICE $\bullet 54$ No. $3 \bullet 2017 \quad$ http://www.revmaterialeplastice.ro
Fig. 5. Degradation analysis of the polycrystalline solar cells

Table 4

DEPENDENCE BETWEEN THE TIMES OF FAILURE AND THE MAIN RELIABILITY INDICATORS OF THE POLYCRYSTALLINE SOLAR CELLS 


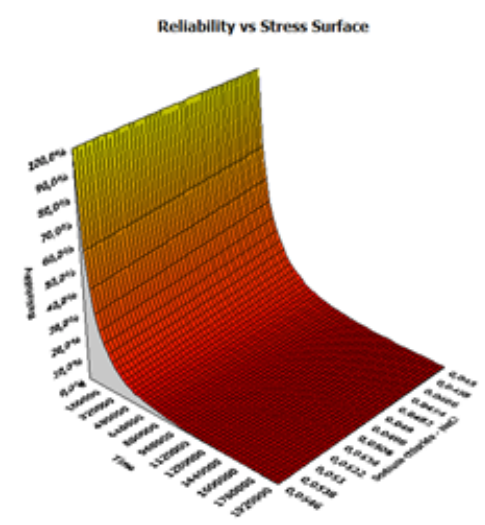

pdf vs Stress Surface

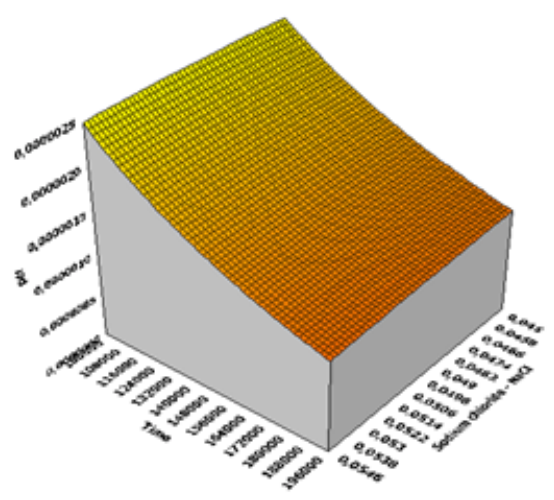

lifetime under normal test conditions (MTBF); acceleration factor; reliability indicators within normal test conditions (reliability function, unreliability function, failure rate, standard deviation, probability density of the operating time).

For a statistical analysis of the results obtained by accelerated reliability tests was used the Inverse Power Law model and Weibull distribution. By using the statistical data processing, the main indicators of reliability (table 4) have been obtained for the failure times corresponding to the 10 polycrystalline solar cells.

In the 3D graphical representation of reliability/ unreliability (fig. 6) are determined and represented the values of reliability/unreliability for different levels of sodium chloride solution concentration using a wider range for the testing time $(0-19200000 \mathrm{~h})$ for polycrystalline solar cells.

On the pdf vs. stress surface plot (fig. 7) the values of the probability density according to the testing time in normal regime and different levels of sodium chloride solution concentration, have been described. In likelihood function surface plot have been represented the values of the maximum likelihood function for two specific parameters (beta and K) for the Inverse Power Law Weibull model.

The main objective of the accelerated reliability tests is to determine the product lifetime in conditions of normal use $(0.05 \% \mathrm{NaCl}$ solution concentration). By using the data resulting from the accelerated reliability tests, obtained from corrosion degradation tests of the solar cells, it can be determined the average number of hours to the failure in normal conditions of use. The average number of hours until failure (fig. 8) for polycrystalline solar cells was 158958 (about 18 years in a favourable environment to occur the damage due to corrosion: $0.05 \% \mathrm{NaCl}$ solution concentration).
Fig. 6. Reliability/Unreliability of the polycrystalline solar cells

Fig. 7. Probability density function and likelihood function surface of the polycrystalline solar cells

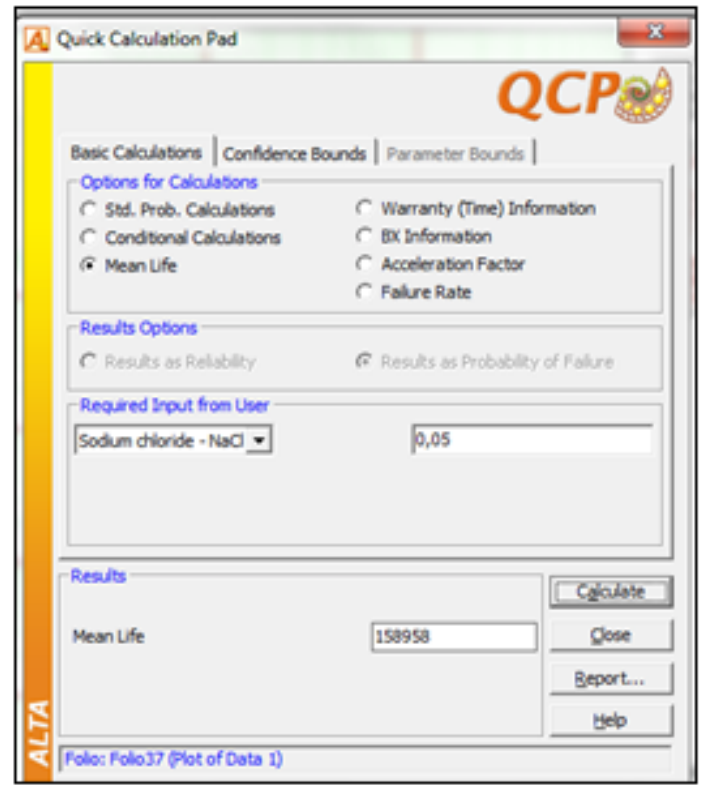

Fig. 8. Mean life of the polycrystalline solar cells

The macroscopic and microscopic analysis of the polycrystalline solar cells subjected to the salt spray test For the polycrystalline solar cells were performed macrostructural analyses (25X magnification) and microstructural (magnification 100X, 200X, 500X, 1000X) to verify the surfaces with salt deposition or areas where the corrosion phenomenon appeared. The macroscopic analysis enables us to choose the areas with problems on the polycrystalline solar cells surface that will be subjected to a microscopic analysis. In table 5. b), e) and h) can be observed the manner in which the corrosion accelerated tests in salt spray ( $5 \% \mathrm{NaCl}$ solution concentration) determined the appearance of the areas with salt deposits and corrosion on the polycrystalline solar cells surface. Taking into account the images presented in table 5. c), f) 


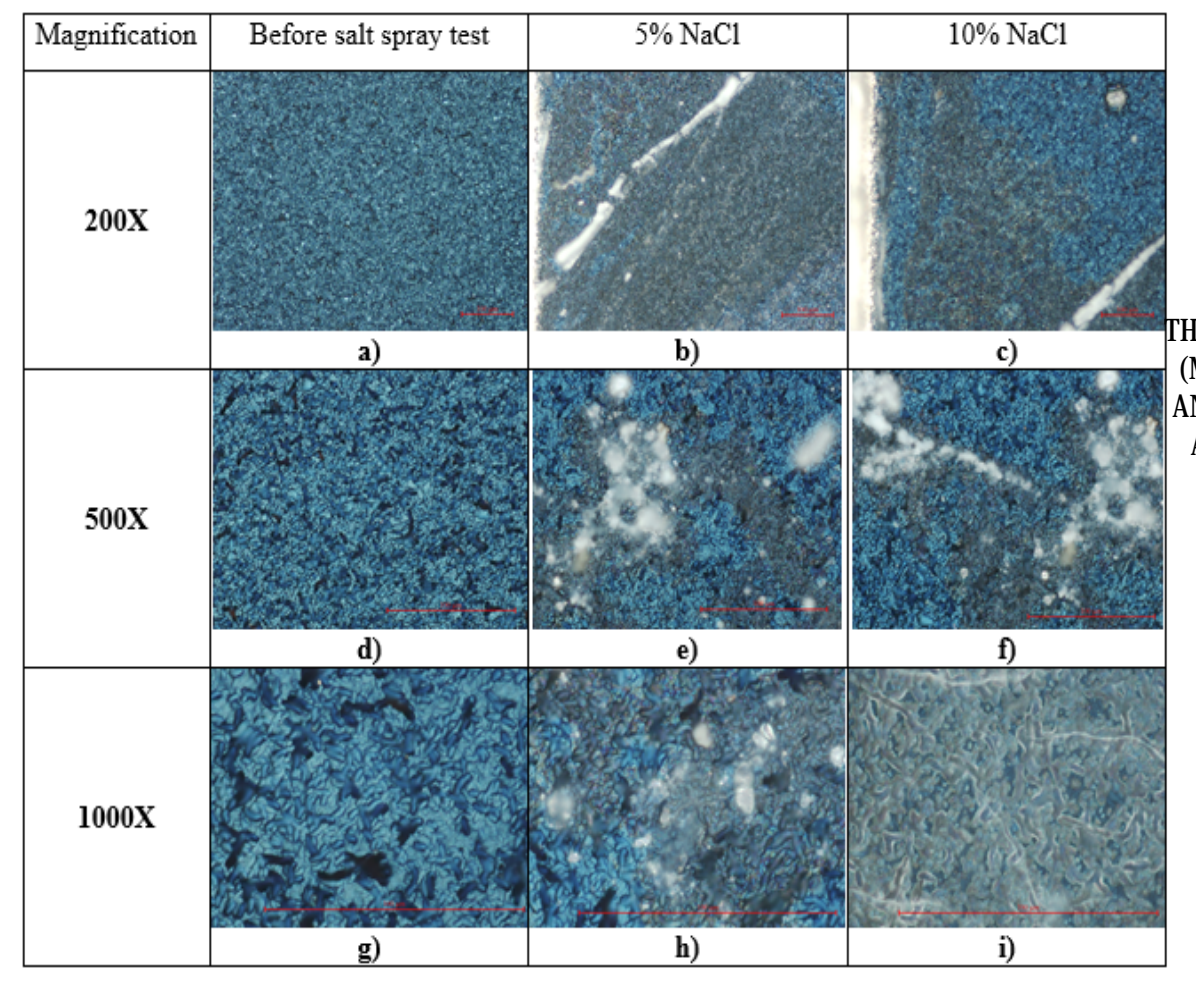

Table 5

HE MICROSCOPIC ANALYSIS OF SOLAR CELLS (MAGNIFICATION 200X, 500X, 1000X) BEFORE AND AFTER THE SALT SPRAY TESTING AT TWO ACCELERATED REGIMES ( $5 \%$ AND $10 \% \mathrm{NaCl}$ SOLUTION CONCENTRATION)

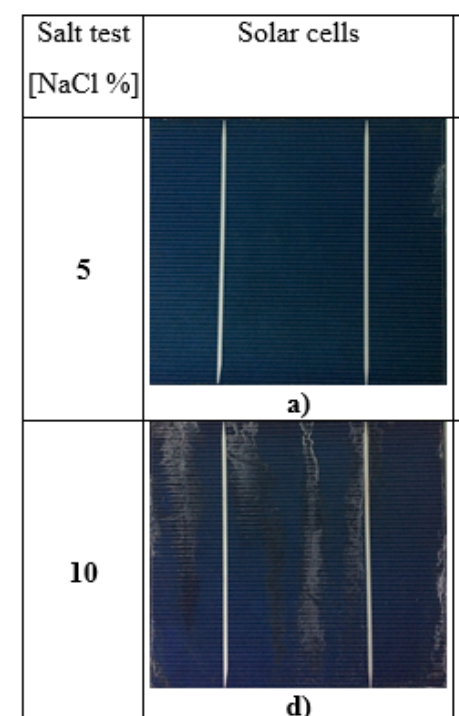

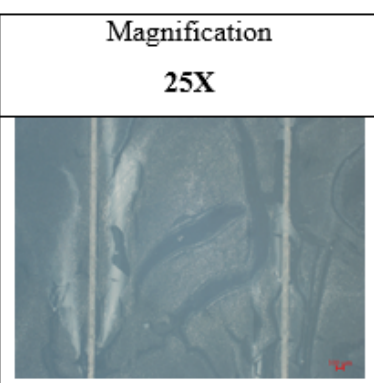

b)

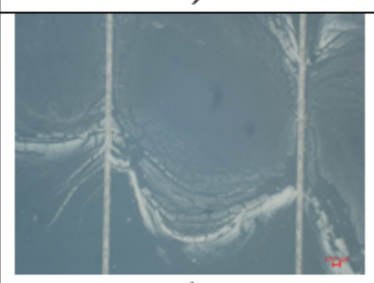

e)

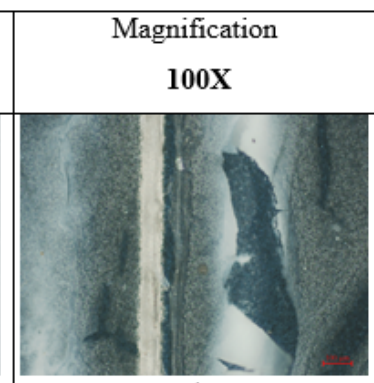

c)

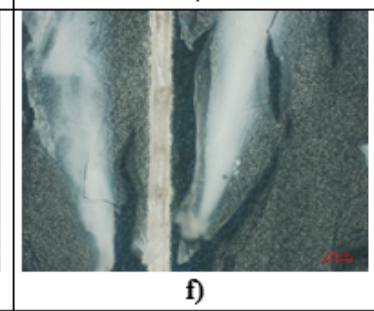

Table 6

VISUAL AND MACROSCOPIC ANALYSIS (MAGNIFICATION 25X)/MICROSCOPIC ANALYSIS (MAGNIFICATION 100X) OF THE SOLAR CELLS AFTER TESTING THE TWO ACCELERATED REGIMES ( $5 \%$ AND $10 \% \mathrm{NaCl}$ SOLUTION CONCENTRATION) and i), it can be said that the performance of the polycrystalline solar cells have been strongly affected at $10 \% \mathrm{NaCl}$ solution concentration and some areas were deeply affected by salt deposits and intense corrosion.

The polycrystalline solar cells tested in saline chamber (at $5 \%$ and $10 \% \mathrm{NaCl}$ solution concentration) were characterized microstructural after 384 hours of testing by using microscopic analysis at 25X and 100X magnification scale (table 6). On the solar cells surfaces can be seen substantial deposition of salt. These areas of salt deposits and corrosion placed in very close proximity of the metal contacts are very dangerous and cause corrosion to the connecting strips and finally to failure the electrical system of the polycrystalline solar cells.

\section{Conclusions}

Currently a special interest is represented by testing the solar cells in a very short time and with very intense testing regimes. Concerns regarding the shortening of testing time and the best cost efficiency for materials have led to the development of new accelerated testing methods. These methods represent priority targets for the companies which producing solar cells of high quality and reliability. In conditions of a fierce competition in the solar energy field, for predicting the lifetime of a solar cell and for selecting the best materials and technologies, aiming technical and economical advantages, has became obvious to all the specialists in the testing field that the best information are obtained by using the cyclic accelerated tests of corrosion.

In this paper was conducted an experimental study on corrosion of polycrystalline solar cells subjected to salt spray test. The testing of these polycrystalline solar cells were performed by accelerated testing techniques at two accelerating levels, under 5 and $10 \% \mathrm{NaCl}$ solution concentration. The results of the degradation analysis were extrapolated using the Power degradation model and have been obtained the data corresponding to the reliability accelerated tests for polycrystalline solar cells.

By using the statistical processing of accelerated data it has been obtained the reliability indicators (reliability function, unreliability function, failure rate, probability density) and mean life which is the main indicator that determines the performance of the solar cells tested to corrosion. In only sixteen days, the corrosion accelerated tests are able to produce a corrosion level equivalent to those obtained in 18 years of using the solar cells in a 
common external medium $(0.05 \% \mathrm{NaCl}$ solution concentration) close to the seas or oceans having saltwater. Also, macroscopic and microscopic analyses were carried out in order to verify and quantify the salt deposition and the corrosion areas on the solar cells surface.

Acknowledgement: We hereby acknowledge the structural founds projectPRO-DD (POS-CCE, 0.2.2.1., ID 123, SMIS2637, ctr. No 11/2009) for providing the infrastructure used in this work.

\section{References}

1. FRAAS, L., PARTAIN, L., Solar Cells and Their Applications, Ed. Wiley, 2010, p. 113

2. GREEN, M. A., Solar cells operating principles, technology and system application, Ed. Prentice Hall, 1998, p.1

3. SEIGNEUR, H., MOHAJERI, N., BROOKER, R. P., DAVIS, K. O., SCHNELLER, E. J., DHERE, N. G., SCHOENFELD, W. V., Renew. Sust. Energ. Rev., 59, 2016, p. 84

4. DAVIS, K. O., RODGERS, M. P., SCARDERA, G., BROOKER, R. P., SEIGNEUR, H., MOHAJ ERI, N., SCHOENFELD. W. V., Renew. Sust. Energ. Rev., 59, 2016, p. 225

5. SCHNELLER, E. J., BROOKER, R. P., SHIRADKAR, N. S., RODGERS, M. P., DHERE, N. G., DAVIS, K. O., SCHOENFELD, W. V., Renew. Sust. Energ. Rev., 59, 2016, p. 992

6. LEE, T. D., EBONG, A. U., Renew. Sust. Energ. Rev., 70, 2017, p. 1286 7.JAHN, U., T.U.V RHEINLAND., PV Module Reliability Issues Including Testing and Certification, European Photovoltaic Solar Energy Conference and Exhibition, 2012

.8. FERRARA, C., PHILIPP, D., Energy Procedia, 15, 2012. p. 379
9. BALL, G., Grounding Photovoltaic Modules: The Lay of the Land, Solar America Board for Codes and Standards Report, 2011

10. KUITCHE, J., TAMIZHMANI, G., Accelerated Lifetime Testing of Photovoltaic Modules Solar America Board for Codes and Standards, A report of Solar America Board for Codes and Standards, 2013

11. NDIAYE, A., CHARKI, A., KOBI, A., CHEIKH, M. F., KEBE, C. M. F., NDIAYE, P. A., SAMBOU, V., Sol. Energy, 96, 2013, p. 140

12. XIONG, H., GAN, C., YANG, X., HU, Z., NIU, H., LI, J., SI, J., XING, P., LUO, X., Microelectron. Reliab., 70, 2017, p. 49

13. LIN, G. J., WANG, L. J., LIU, J. Q., XIONG, W. P., SONG, M. H., WU, Z. H., Procedia Environ. Sci., 11, 2011, p. 1147

14. TSANAKAS, J.A., SICRE, M., CARRIERE, C., ELOUAMARI, R., VOSSIER, A., DE SALINS, J.-E., LEVRIER, B., DOLLET, A., Sol. Energy, 116, 2015, p. 205

15. HAN, X., WANG, Y., ZHU, L., XIANG. H., ZHANG. H., Sol. Energy, 85, 2011, p. 2781

16. SIDDIQUI, R., KUMAR, R., JHA, G. K., GOWRI, G., MORAMPUDI, M., RAJ PUT, P., LATA, S., AGARIYA, S., DUBEY, B., NANDA, G., RAGHAVA, S. S., Energy, 107, 2016, p. 550

17. CALDWELL, W., PARKER, T. P., HASSELBRINK, C., Procedia Engineering, 139, 2016, p. 155

18. SCHULLER, S., SCHILINSKY, P., HAUCH, J., BRABEC, C., J. Applied Physics A, 79, 2004, p. 37

19. CHARKI, A., LARONDE, R., BIGAUD, D., J . of Photon. Energy., 3, 2013, p. 033099

20. ZAHARIA, S. M., MARTINESCU, I., Teh Vjesn., 23, no. 5, 2016, p. 1447

21. ZAHARIA, S. M., MARTINESCU, I., MORARIU, C. O., Eksploat. Niezawodn., 14, no. 2, 2012, p. 99

Manuscript received: 7.02 .2017 